\title{
Effect of Nitrogen Fertilizer on Irrigated Forage Pearl Millet (Pennisetum americanum L.K. Shcum)
}

\author{
Yassin Mohamed Ibrahim, Atif Elsadig Idris*, Mohamed Abd-Elfatah Marhoum \\ Department of Agronomy, College of Agricultural Studies, Sudan University of Science and Technology, P.O. Box71, Shambat, Sudan \\ *Corresponding Author: atifelsadig@gmail.com
}

Copyright (C) 2014 Horizon Research Publishing All rights reserved.

\begin{abstract}
An experiment was conducted at the demonstration farm, College of Agricultural Studies, Sudan University of Science and technology, Shambat during April to July 2008 and April to July 2009 to study the effect of nitrogen fertilizer on two local cultivars of pearl millet (Wad Ahana and Dembi) under irrigation conditions. The experiments were conducted by using a split plot arrangement, two cultivars as main plots and the five nitrogen levels as sub plots. The parameters measured were fresh weight $(\mathrm{kg})$, dry weight $(\mathrm{kg})$, plant height $(\mathrm{cm})$, number of tillers/plant, stem diameter $(\mathrm{cm})$, number of leaves/plant and forage fresh weight ( $\mathrm{t} / \mathrm{ha})$. The statistical analysis was recorded to separate the means. The results revealed positive significant effects on fresh weight, dry weight, number of leaves/plant and forage yield which indicate the ability to grow millet successfully during April as a forage crop. The results recorded that additional nitrogen rate of $120 \mathrm{~kg} \mathrm{~N} / \mathrm{fed}$ obtained significant effects in both seasons. The results showed that Dembi cultivar has a wide response to nitrogen fertilizer under irrigation conditions in both seasons. This study cleared that local cultivars of pearl millet could not obtain positive grain yield due to the effect of temperature and a long day light in April - July, but it was good for forage yield. Furthermore, local cultivars of millet need more genetic and selective experiments to create a new resistant type.
\end{abstract}

Keywords Fertilizer, Forage, Nitrogen, Pearl Millet, Cultivars

\section{Introduction}

Pearl millet (Pennisetum americanum [L.] R.Br.) is one of the most important crops which grow in the arid and semiarid areas in the world for both food and forage production. Millet is well adapted to conditions of light soil, high temperature, high solar radiation and able to have high growth rate and water use efficiency under favorable rain fed conditions. Once crop has been established, it has a high degree of drought to tolerance, but it was sensitive to the high level of temperature during the last stage of growth (flowering and maturity). Being one of the most drought tolerance crops, millet has a great potential in the semi - arid areas (Vanderlip,1991).

The crop is considered as an important grain crop in Africa where the rain fall is not secure enough for sorghum or maize. In the United States and Australia it is useful, non-toxic forage to replace forage sorghum. The stalks are used in the dry tropics for home building. The crop can yield an average of $25.2 \mathrm{t} /$ ha of green matter (Bank and Stewart, 2008).

Wilson (2009) found that peal millet was equivalent to Sudan grass and sorghum $\mathrm{X}$ Sudan grass hybrids for dry matter yield, carrying capacity and grain yield. The origin of millet is diverse with varieties coming from both Africa and Asia (ICRISAT, 2009). Millet is one of the most important basic crops in rural areas of the Sudan (Kordofan, Darfor, South Blue Nile, Gadarif States) where most of the stable people in these areas depend on millet as their main food. Most of the millet is grown for both grain and fodder under rain fed ( Abdelrahman 2007 and Abuali et al. 2012). Most of fertilization work on pearl millet was done for grain production. Scanty work was found for both millet growth under irrigation and/or for forage production (Ibrahim1996 and Siddig, 2002) and little information is available. Therefore, the present study was conducted to study the response of two millet cultivars to nitrogen fertilizer (urea) under irrigation, suggesting the best dose of urea under such conditions and to differentiate between the production forage millet cultivars.

\section{Materials and Methods}

Field experiments were conducted into two successive seasons (April to July 2008 - April to July 2009) to investigate the effect of nitrogen fertilizer on forage millet grown under streamlined irrigation at the experimental farm, College of Agricultural Studies, Sudan University of Science and Technology, Shambat, ( $\left.15^{\circ} 40^{\prime} \mathrm{N}, 32^{\circ} 32^{\prime} \mathrm{E}\right)$, Sudan. The experiments were conducted by using a split plot arrangement. The treatments consisted of two traditional pearl millet (Pennisetum americanum [L.] R.Br.) cultivars, 
yellow and white millet (Wad Alshana and Dembi) as the main plots and five levels of nitrogen fertilizer in urea form $(46 \% \mathrm{~N})$ at the rates $0,40,80,120,160 \mathrm{~kg} \mathrm{~N} / \mathrm{ha}$ as subplots. The treatments were arranged in randomized complete block design (RCBD) with four replications. The crop was irrigated every 7-10 days according to field capacity (FC) and the cultural operations were performed as practice in the area. The parameters measured were fresh weight $(\mathrm{kg})$, dry weight $(\mathrm{kg})$, plant height $(\mathrm{cm})$, number of tillers/plant, stem diameter $(\mathrm{cm})$, number of leaves/plant and forage yield ( $\mathrm{t} / \mathrm{ha})$. The data was subjected to statistical analysis to determine the significance using $\mathrm{F}$. test (ANOVA). Duncan multiple range test (DMRT) at 0.05 percent level of significance was performed for mean separation according to Gomez and Gomez (1984). The data was analyzed by M.STAT-C computer program.

\section{Results \& Discussion}

Tables $1 \mathrm{a}$ and $1 \mathrm{~b}$ illustrate the effect of nitrogen fertilizer on yellow and white millet during both seasons. The results showed that the fresh weight increased with increasing nitrogen fertilizer till $160 \mathrm{~kg} / \mathrm{ha}$ for both seasons.

There is no significant difference between Wad Ashana and Dembi cultivars. (Table, 1b) showed significant difference between 40,80 and $120 \mathrm{~kg} \mathrm{~N} / \mathrm{ha}$ compared with control while $160 \mathrm{~kg} \mathrm{~N} / \mathrm{ha}$ showed highly significant difference at season 2009/2008 and no significant difference in seasons 2008/2009. Similar results were obtained by Dass and Singh (1979) as they noted that nitrogen content was higher for plant growth in loamy sand soil than in sandy loam soil. Additionally, Siddig (2002) showed that shoot weights were significantly affected by nitrogen and phosphorus. The results of the dry weight showed similar trend. The dry weight of the control and $40 \mathrm{~kg} \mathrm{~N} / \mathrm{ha}$ were not significantly different but the mean increased with increasing nitrogen levels of $80 \mathrm{~kg} \mathrm{~N} / \mathrm{ha}, 120 \mathrm{~kg} \mathrm{~N} / \mathrm{ha}$ and $160 \mathrm{~kg} \mathrm{~N} / \mathrm{ha}$ (tables 2a, 2b). At season 2009 the result showed that the effect of nitrogen on dry weight was not significant (table, 2a).

Table (1a). Effect of nitrogen fertilizer of fresh weight $(\mathrm{kg})$ of millet cultivars

\begin{tabular}{|ccccccc|}
\hline \multicolumn{3}{|c}{ Season 2007-2008 } & \multicolumn{5}{c|}{ Season 2008 - 2009 } \\
\multicolumn{4}{c}{ Cultivars } & \multicolumn{5}{c|}{$\begin{array}{c}\text { Cultivars } \\
\text { Nad } \\
\text { Nitrogen }\end{array}$} & $\begin{array}{c}\text { Wad } \\
\text { Ashana }\end{array}$ & Dembi & Means & Ashana & Dembi & Means \\
0 & 1.50 & 1.60 & $1.55 \mathrm{~b}$ & 2.85 & 1.66 & $2.25 \mathrm{a}$ \\
40 & 1.81 & 1.65 & $1.73 \mathrm{~b}$ & 2.87 & 2.50 & $2.68 \mathrm{a}$ \\
80 & 1.85 & 1.65 & $1.75 \mathrm{~b}$ & 2.97 & 2.51 & $2.74 \mathrm{a}$ \\
120 & 1.92 & 1.68 & $1.80 \mathrm{~b}$ & 3.34 & 3.02 & $3.18 \mathrm{a}$ \\
160 & 2.16 & 2.22 & $2.19 \mathrm{a}$ & 3.38 & 3.16 & $3.27 \mathrm{a}$ \\
Means & 1.85 & 1.76 & & 3.08 & 2.57 & \\
SE \pm & & & 110.03 & & & 386.29 \\
C.V\% & & & 17.25 & & & 38.64 \\
\hline
\end{tabular}

Table (1b). Effect of millet cultivar and nitrogen fertilizer on fresh weight $(\mathrm{kg})$

\begin{tabular}{|cccc|}
\hline & Nitrogen/kg & $2007-2008$ & $2008-2009$ \\
& 0 & $1.5 \mathrm{c}$ & $1.7 \mathrm{a}$ \\
Wad Ashana & 40 & $1.8 \mathrm{abc}$ & $2.5 \mathrm{a}$ \\
& 80 & $1.8 \mathrm{abc}$ & $2.5 \mathrm{a}$ \\
& 120 & $1.9 \mathrm{abc}$ & $3.0 \mathrm{a}$ \\
Mean & 160 & $2.2 \mathrm{ab}$ & $3.2 \mathrm{a}$ \\
SE \pm & & 1.8 & 2.57 \\
& & 110.03 & 386.29 \\
& 0 & $1.6 \mathrm{c}$ & $2.8 \mathrm{a}$ \\
Dembi & 40 & $1.6 \mathrm{c}$ & $2.9 \mathrm{a}$ \\
& 80 & $1.6 \mathrm{c}$ & $3.0 \mathrm{a}$ \\
& 120 & $1.7 \mathrm{bc}$ & $3.3 \mathrm{a}$ \\
Mean & 160 & $2.2 \mathrm{a}$ & $3.4 \mathrm{a}$ \\
SE \pm & & 1.76 & 3.08 \\
& & 155.6 & 546.3 \\
\hline
\end{tabular}

Means followed by the same letter within each column are not significant according to DMR test at $5 \%$.

Table (2a). Effect of nitrogen fertilizer on dry weight $(\mathrm{kg})$ of millet cultivars

\begin{tabular}{|c|c|c|c|c|c|c|}
\hline \multicolumn{4}{|c|}{ Season 2007-2008 } & \multicolumn{3}{|c|}{ Season $2008-2009$} \\
\hline & Cult & & & Cult & & \\
\hline Nitrogen & $\begin{array}{c}\text { Wad } \\
\text { Ashana }\end{array}$ & Dembi & Means & $\begin{array}{c}\text { Wad } \\
\text { Ashana }\end{array}$ & Dembi & Means \\
\hline 0 & 0.49 & 0.49 & $0.49 \mathrm{~b}$ & 1.14 & 0.74 & $0.94 \mathrm{a}$ \\
\hline 40 & 0.59 & 0.62 & $0.61 \mathrm{ab}$ & 1.22 & 1.00 & $1.11 \mathrm{a}$ \\
\hline 80 & 0.60 & 0.70 & $0.65 \mathrm{a}$ & 1.32 & 1.07 & $1.20 \mathrm{a}$ \\
\hline 120 & 0.63 & 0.68 & $0.66 \mathrm{a}$ & 1.69 & 1.22 & $1.45 \mathrm{a}$ \\
\hline 160 & 0.68 & 0.80 & $0.74 \mathrm{a}$ & 1.67 & 1.32 & $1.49 \mathrm{a}$ \\
\hline Means & 0.60 & 0.66 & & 1.41 & 1.07 & \\
\hline $\mathrm{SE} \pm$ & & & 47.2 & & & 174.95 \\
\hline C.V\% & & & 21.23 & & & 39.97 \\
\hline
\end{tabular}

Table (2b). Effect of millet cultivar and nitrogen fertilizer on dry weight $(\mathrm{kg})$

\begin{tabular}{|cccc|}
\hline & Nitrogen/kg & $2007-2008$ & $2008-2009$ \\
& 0 & $0.49 \mathrm{~b}$ & $0.74 \mathrm{~b}$ \\
& 40 & $0.59 \mathrm{ab}$ & $1.00 \mathrm{ab}$ \\
Wad Ashana & 80 & $0.60 \mathrm{ab}$ & $1.07 \mathrm{ab}$ \\
& 120 & $0.63 \mathrm{ab}$ & $1.22 \mathrm{ab}$ \\
& 160 & $0.68 \mathrm{ab}$ & $1.32 \mathrm{ab}$ \\
Mean & & 0.60 & 1.07 \\
SE \pm & & 47.2 & 174.95 \\
& 0 & $0.49 \mathrm{~b}$ & $1.14 \mathrm{ab}$ \\
& 40 & $0.62 \mathrm{ab}$ & $1.22 \mathrm{ab}$ \\
Dembi & 80 & $0.70 \mathrm{ab}$ & $1.32 \mathrm{ab}$ \\
& 120 & $0.68 \mathrm{ab}$ & $1.68 \mathrm{a}$ \\
& 160 & $0.80 \mathrm{a}$ & $1.67 \mathrm{a}$ \\
Mean & & 0.66 & 1.41 \\
SE \pm & & 66.71 & 247.4 \\
\hline
\end{tabular}

Means followed by the same letter within each column are not significant according to DMR test at $5 \%$. 
The effect between millet cultivars and nitrogen at season 2008 showed that dry weight was not significant through all levels except between control and $160 \mathrm{~kg} \mathrm{~N} / \mathrm{ha}$ (table, $2 \mathrm{~b}$ ), but increasing of nitrogen level to $120-160 \mathrm{~kg} \mathrm{~N} / \mathrm{ha}$ affect dry weight significantly in season 2009. These results indicate that both cultivars did not utilize the additional nitrogen at the first season. According to Marionville (1989) lack of nitrogen resulted in poor plant growth.

Table (3a). Effect of nitrogen fertilizer on plant height $(\mathrm{cm})$ of millet cultivars

\begin{tabular}{|ccccccc|}
\hline \multicolumn{3}{|c}{ Season 2007-2008 } & \multicolumn{5}{c|}{ Season 2008 - 2009 Cultivar } \\
Nitrogen & $\begin{array}{c}\text { Wad } \\
\text { Ashana }\end{array}$ & Dembi & Means & $\begin{array}{c}\text { Wad } \\
\text { Ashana }\end{array}$ & Dembi & Means \\
0 & 119 & 137 & $127.9 \mathrm{c}$ & 124 & 156 & $140 \mathrm{~b}$ \\
40 & 120 & 164 & $136.9 \mathrm{bc}$ & 143 & 150 & $151 \mathrm{ab}$ \\
80 & 126 & 162 & $143.8 \mathrm{bc}$ & 144 & 161 & $152 \mathrm{ab}$ \\
120 & 131 & 169 & $150.2 \mathrm{ab}$ & 169 & 176 & $172 \mathrm{a}$ \\
160 & 154 & 172 & $163.1 \mathrm{a}$ & 169 & 173 & $171 \mathrm{a}$ \\
Means & 130 & 159 & & 150 & 165 & \\
SE \pm & & & 5.21 & & & 6.997 \\
C.V\% & & & 10.22 & & & 12.58 \\
\hline
\end{tabular}

Table (3b). Effect of millet cultivar and fertilizer on plant height (cm)

\begin{tabular}{cccc|}
\hline & Nitrogen/kg & $2007-2008$ & $2008-2009$ \\
& 0 & $119.5 \mathrm{c}$ & $155.8 \mathrm{a}$ \\
Wad Ashana & 40 & $119.8 \mathrm{c}$ & $159.7 \mathrm{a}$ \\
& 80 & $125.7 \mathrm{c}$ & $160.8 \mathrm{a}$ \\
& 120 & $131.2 \mathrm{bc}$ & $175.5 \mathrm{a}$ \\
Mean & 160 & $154.3 \mathrm{ab}$ & $173.0 \mathrm{a}$ \\
SE \pm & & 130 & 165 \\
& & 5.21 & 6.997 \\
& 0 & $136.7 \mathrm{bc}$ & $123.8 \mathrm{~b}$ \\
Dembi & 40 & $153.9 \mathrm{ab}$ & $142.8 \mathrm{ab}$ \\
& 120 & $161.8 \mathrm{a}$ & $143.9 \mathrm{ab}$ \\
& 160 & $169.1 \mathrm{a}$ & $169.4 \mathrm{a}$ \\
Mean & & $171.9 \mathrm{a}$ & $168.8 \mathrm{a}$ \\
SE \pm & & 159 & 150 \\
\hline
\end{tabular}

Means followed by the same letter within each column are not significant according to DMR test at $5 \%$.

In both seasons there was a significant difference in plant height (table, 3a) with increasing of nitrogen level, except at $40 \mathrm{~kg} \mathrm{~N} / \mathrm{ha}$ and $80 \mathrm{~kg} \mathrm{~N} / \mathrm{ha}$. Cultivars plant height was significant at $120 \mathrm{~kg} \mathrm{~N} / \mathrm{ha}$ and $160 \mathrm{~kg} \mathrm{~N} / \mathrm{ha}$ in season 2008 . Furthermore, the effect was significant at $120 \mathrm{~kg} \mathrm{~N} / \mathrm{ha}$ and $160 \mathrm{~kg} \mathrm{~N} / \mathrm{ha}$ compared with control in both seasons. The interaction effect on plant height was not significant except at $160 \mathrm{~kg} \mathrm{~N} / \mathrm{ha}$ for Wad Ashana and $80 \mathrm{~kg} \mathrm{~N} / \mathrm{ha}, 120 \mathrm{~kg} \mathrm{~N} / \mathrm{ha}$ and $160 \mathrm{~kg} \mathrm{~N} / \mathrm{ha}$ for Dembi in season 2008 (table, 3b). At season 2009 the effect of nitrogen was not significant during all levels at Wad Ashana (Yellow), while it was significant at $160 \mathrm{~kg} \mathrm{~N} / \mathrm{ha}$ at Dembi (white). The active effect of nitrogen on plant height was reported by Adam (2004).

The highest numbers of tillers ( 18 for Wad Ashana and 16 for Dembi) were observed at $160 \mathrm{~kg} \mathrm{~N} / \mathrm{ha}$ at the first season for Wad Ashana and at the second season for Dembi (table, 4a). On the other hand, the lowest number of tillers recorded (11 and 13) were observed for the level of nitrogen control, $40 \mathrm{~kg} \mathrm{~N} / \mathrm{ha}$ and $80 \mathrm{~kg} \mathrm{~N} / \mathrm{ha}$, respectively and noted on the first season and second season respectively for Dembi cultivar (table, 4b). The conditions were more favorable in the second season. Increase in tillers number with increased nitrogen was obvious as nitrogen promotes the plant growth. Positive effects of nitrogen or number of tillers were reported by many researchers: (Reddy et al. 1986 and Frank et Al. 1988).

Table (4a). Effect of nitrogen fertilizer on number of tillers of millet cultivars

\begin{tabular}{|ccccccc|}
\hline \multicolumn{3}{|c}{ Season 2007-2008 } & \multicolumn{5}{c|}{ Season 2008 - 2009 } \\
\multicolumn{4}{c}{ Cultivar } & \multicolumn{4}{c|}{$\begin{array}{c}\text { Cultivar } \\
\text { Nitrogen }\end{array}$} & $\begin{array}{c}\text { Wad } \\
\text { Ashana }\end{array}$ & Dembi & Means & $\begin{array}{c}\text { Ashana } \\
\text { Aembi }\end{array}$ & Means \\
0 & 14 & 11 & $12.4 \mathrm{a}$ & 15 & 14 & $14 \mathrm{a}$ \\
40 & 16 & 11 & $13.3 \mathrm{a}$ & 16 & 13 & $14 \mathrm{a}$ \\
80 & 15 & 12 & $13.2 \mathrm{a}$ & 15 & 13 & $14 \mathrm{a}$ \\
120 & 17 & 13 & $14.7 \mathrm{a}$ & 16 & 14 & $15 \mathrm{a}$ \\
160 & 18 & 13 & $15.4 \mathrm{a}$ & 16 & 16 & $16 \mathrm{a}$ \\
Means & 16 & 12 & & 15 & 14 & \\
SE \pm & & & 0.93 & & & 1.444 \\
C.V\% & & & 19.07 & & & 27.81 \\
\hline
\end{tabular}

Table (4b). Effect of millet cultivars and fertilizer on number of tillers

\begin{tabular}{|cccc|}
\hline & Nitrogen/kg & $2007-2008$ & $2008-2009$ \\
& 0 & $14.2 \mathrm{abc}$ & $13.6 \mathrm{a}$ \\
Wad Ashana & 40 & $15.6 \mathrm{ab}$ & $13.1 \mathrm{a}$ \\
& 80 & $17.2 \mathrm{a}$ & $13.3 \mathrm{a}$ \\
& 120 & $14.4 \mathrm{abc}$ & $14.3 \mathrm{a}$ \\
Mean & 160 & $18.0 \mathrm{a}$ & $15.7 \mathrm{a}$ \\
SE \pm & & 15 & 14 \\
& & 0.93 & 1.444 \\
& 0 & $11.1 \mathrm{c}$ & $14.6 \mathrm{a}$ \\
Dembi & 40 & $10.4 \mathrm{c}$ & $15.5 \mathrm{a}$ \\
& 80 & $10.0 \mathrm{c}$ & $15.4 \mathrm{a}$ \\
& 120 & $11.0 \mathrm{c}$ & $15.6 \mathrm{a}$ \\
Mean & 160 & $12.5 \mathrm{c}$ & $15.9 \mathrm{a}$ \\
SE \pm & & 12 & 15 \\
\hline
\end{tabular}

Means followed by the same letter within each column are not significant according to DMR test at $5 \%$. 
The effect of nitrogen doses on stem diameter is different between high and low dose and the highest effect was recorded at $120 \mathrm{~kg} \mathrm{~N} / \mathrm{ha}$ and $160 \mathrm{~kg} \mathrm{~N} / \mathrm{ha}$ on both cultivars at the first season. The lowest diameter was showed at $0 \mathrm{~kg}$ $\mathrm{N} / \mathrm{ha}, 40 \mathrm{~kg} \mathrm{~N} / \mathrm{ha}$ and $80 \mathrm{~kg} \mathrm{~N} / \mathrm{ha}$ (table, 5a). On the other hand, the results showed that diameter of stem were generally increased on the second season but not significantly different between treatments. The favorable climatic conditions were better at the second season. This results refers to the effect of the additional nitrogen not utilized fully in the first season.

Table (5a). Effect of nitrogen fertilizer on stem diameter $(\mathrm{cm})$ of millet cultivars

\begin{tabular}{|ccccccc|}
\hline \multicolumn{3}{|c}{ Season 2007-2008 } & \multicolumn{5}{c|}{$\begin{array}{c}\text { Season 2008 - 2009 Cultivar } \\
\text { Cultivar } \\
\text { Nitrogen } \\
\text { Wad } \\
\text { Ashana }\end{array}$} & Dembi & Means & $\begin{array}{c}\text { Wad } \\
\text { Ashana }\end{array}$ & Dembi & Means \\
0 & 3.4 & 3.7 & $3.5 \mathrm{c}$ & 4.7 & 4.9 & 4.8 \\
40 & 3.4 & 3.8 & $3.6 \mathrm{bc}$ & 5.2 & 5.0 & 5.1 \\
80 & 3.5 & 3.9 & $3.7 \mathrm{bc}$ & 4.6 & 5.0 & 4.8 \\
120 & 3.7 & 3.9 & $3.8 \mathrm{ab}$ & 5.1 & 4.7 & 4.9 \\
160 & 4.2 & 3.9 & $4.1 \mathrm{a}$ & 4.4 & 4.9 & 4.7 \\
Means & 3.6 & 3.8 & & 4.8 & 4.9 & \\
SE \pm & & & 0.0898 & & & 0.16 \\
C.V\% & & & 6.78 & & & 9.7 \\
\hline
\end{tabular}

Table (5b). Effect of millet cultivars and fertilizer on on stem diameter (cm)

\begin{tabular}{|cccc|}
\hline & Nitrogen/kg & $2007-2008$ & $2008-2009$ \\
& 0 & $3.4 \mathrm{~d}$ & $4.7 \mathrm{a}$ \\
Wad Ashana & 40 & $3.4 \mathrm{~cd}$ & $5.2 \mathrm{a}$ \\
& 80 & $3.5 \mathrm{bcd}$ & $4.6 \mathrm{a}$ \\
& 120 & $4.0 \mathrm{ab}$ & $5.1 \mathrm{a}$ \\
Mean & 160 & $4.1 \mathrm{a}$ & $4.4 \mathrm{a}$ \\
SE \pm & & 3.6 & 4.8 \\
& & 0.0898 & 0.1668 \\
& 0 & $3.7 \mathrm{abcd}$ & $4.9 \mathrm{a}$ \\
Dembi & 40 & $3.8 \mathrm{abcd}$ & $5.0 \mathrm{a}$ \\
& 80 & $3.8 \mathrm{abcd}$ & $5.0 \mathrm{a}$ \\
& 120 & $3.9 \mathrm{abcd}$ & $4.7 \mathrm{a}$ \\
Mean & 160 & $4.0 \mathrm{abc}$ & $5.0 \mathrm{a}$ \\
SE \pm & & 3.9 & 4.9 \\
\hline
\end{tabular}

Means followed by the same letter within each column are not significant according to DMR test at 5\%.

Tables (6a) and (6b) showed the effect of nitrogen on millet cultivars. Number of leaves increased with the increase in nitrogen dose especially on the yellow millet. The highest number of leaves (28) was observed on Wad Ahsana in the second season and the lowest number on Dembi in both seasons (table, 6a). Number of leaves was not significant at all level of nitrogen in the second season (2009) in spite of the increased number of leaves per plant. The effect was significant at $120 \mathrm{~kg} \mathrm{~N} / \mathrm{ha}$ on yellow millet compared with control on Dembi in 2008 (table, 6b). the increase in leaves number with increasing nitrogen was explained by the fact that nitrogen promotes the vegetative growth, hence number of leaves. This was in harmony with the results of Adam (2004).

The results showed that forage yield was significant at levels of $120 \mathrm{~kg} \mathrm{~N} / \mathrm{ha}$ and $160 \mathrm{~kg} \mathrm{~N} / \mathrm{ha}$ in the first season 2008 (table, 7) and level of nitrogen $160 \mathrm{~kg} \mathrm{~N} / \mathrm{ha}$ in the second season 2009. The significant effect of nitrogen on forage yield revealed that $120 \mathrm{~kg} \mathrm{~N} / \mathrm{ha}$ and $160 \mathrm{~kg} \mathrm{~N} / \mathrm{ha}$ were highly significant for Dembi at both seasons (table, 7). Forage yield of Wad Ashana in 2009 was higher than 2008 for all nitrogen levels and the highest yield obtained was $48.80 \mathrm{t} / \mathrm{ha}$ and $72.87 \mathrm{t} / \mathrm{ha}$ at $160 \mathrm{~kg} \mathrm{~N} / \mathrm{ha}$ for 2008 and 2009 respectively. The same trend was obtained for Dembi. The increase of yield with increasing nitrogen dose was a reflect of the growth being promoted by nitrogen which is reflected on yield. Similar result was obtained by Khadar et al. (1979) who reported higher yields with increasing levels of nitrogen.

Table (6a). Effect of nitrogen fertilizer on number of leaves of millet cultivars

\begin{tabular}{|ccccccc|}
\hline \multicolumn{3}{|c}{ Season 2007-2008 } & \multicolumn{4}{c|}{ Season 2008 - 2009 } \\
\multicolumn{4}{c}{ Cultivar } \\
Nitrogen & $\begin{array}{c}\text { Wad } \\
\text { Ashana }\end{array}$ & Dembi & Means & $\begin{array}{c}\text { Wad } \\
\text { Ashana }\end{array}$ & Dembi & Means \\
0 & 14.4 & 13.3 & $13.8 \mathrm{~b}$ & 23 & 12.8 & $17.7 \mathrm{a}$ \\
40 & 16.7 & 13.6 & $15.1 \mathrm{ab}$ & 14.5 & 15.5 & $15 \mathrm{a}$ \\
80 & 15.9 & 14.2 & $15.1 \mathrm{ab}$ & 14 & 16.1 & $15 \mathrm{a}$ \\
120 & 16.5 & 14.5 & $15.5 \mathrm{ab}$ & 28 & 16.6 & $21 \mathrm{a}$ \\
160 & 16.6 & 15.3 & $15.9 \mathrm{a}$ & 18 & 15.1 & $17 \mathrm{a}$ \\
Means & 16 & 14.2 & & 19.4 & & \\
SE \pm & & & 0.64 & & & 1.993 \\
C.V\% & & & 11.96 & & & 32.62 \\
& & & & & & \\
\hline
\end{tabular}

Table (6b). Effect of millet cultivars and nitrogen fertilizer on number of leaves

\begin{tabular}{|cccc|}
\hline & Nitrogen/kg & $2007-2008$ & $2008-2009$ \\
& 0 & $14.4 \mathrm{abc}$ & $12.8 \mathrm{c}$ \\
Wad Ashana & 40 & $16.6 \mathrm{a}$ & $15.5 \mathrm{bc}$ \\
& 80 & $16.0 \mathrm{abc}$ & $16.2 \mathrm{bc}$ \\
& 120 & $16.5 \mathrm{ab}$ & $14.5 \mathrm{bc}$ \\
Mean & 160 & $16.6 \mathrm{a}$ & $16.7 \mathrm{bc}$ \\
SE \pm & & 16 & 15.1 \\
& & 0.64 & 1.993 \\
& 0 & $13.3 \mathrm{c}$ & $22.7 \mathrm{ab}$ \\
Dembi & 40 & $13.6 \mathrm{bc}$ & $14.6 \mathrm{bc}$ \\
& 80 & $14.2 \mathrm{abc}$ & $14.0 \mathrm{bc}$ \\
& 120 & $14.1 \mathrm{abc}$ & $27.7 \mathrm{a}$ \\
Mean & 160 & $15.2 \mathrm{abc}$ & $18.0 \mathrm{bc}$ \\
SE \pm & & 14.2 & 19.4 \\
& & 0.9028 & 2.818 \\
\hline
\end{tabular}

Means followed by the same letter within each column are not significant according to DMR test at $5 \%$. 
Table (7). Forage yield (T/Fed.) for yellow and white millet cultivars as affected by nitrogen fertilizer

\begin{tabular}{|ccccccccc|}
\hline & \multicolumn{3}{c}{ Season 2007-2008 } & \multicolumn{3}{c}{ Season 2008-2009 } \\
Nitrogen kg/f & $\begin{array}{c}\text { Means fresh } \\
\text { wt (kg) }\end{array}$ & $\begin{array}{c}\text { Forage yield } \\
\text { yellow millet } \\
(\mathrm{T} / \mathrm{F})\end{array}$ & $\begin{array}{c}\text { Means fresh } \\
\text { wt }(\mathrm{kg})\end{array}$ & $\begin{array}{c}\text { Forage yield } \\
\text { yellow millet } \\
(\mathrm{T} / \mathrm{F})\end{array}$ & $\begin{array}{c}\text { Means fresh } \\
\mathrm{wt}(\mathrm{kg})\end{array}$ & $\begin{array}{c}\text { Forage yield } \\
\text { yellow millet } \\
(\mathrm{T} / \mathrm{F})\end{array}$ & $\begin{array}{c}\text { Means fresh } \\
\text { wt }(\mathrm{kg})\end{array}$ & $\begin{array}{c}\text { Forage yield } \\
\text { yellow } \\
\mathrm{millet}(\mathrm{T} / \mathrm{F})\end{array}$ \\
0 & 1.55 & $34.54 \mathrm{~b}$ & 1.60 & $35.66 \mathrm{~b}$ & 2.25 & $50.14 \mathrm{~b}$ & 1.66 & $36.99 \mathrm{c}$ \\
40 & 1.73 & $38.55 \mathrm{~b}$ & 1.65 & $36.77 \mathrm{~b}$ & 2.68 & $59.72 \mathrm{~b}$ & 2.50 & $55.71 \mathrm{~b}$ \\
80 & 1.75 & $39.00 \mathrm{ab}$ & 1.65 & $36.77 \mathrm{~b}$ & 2.74 & $61.06 \mathrm{ab}$ & 2.51 & $55.71 \mathrm{~b}$ \\
120 & 1.80 & $40.119 \mathrm{a}$ & 1.68 & $37.43 \mathrm{ab}$ & 3.18 & $70.86 \mathrm{ab}$ & 3.02 & $67.30 \mathrm{a}$ \\
160 & 2.9 & $48.80 \mathrm{a}$ & 2.22 & $49.47 \mathrm{a}$ & 3.27 & $72.87 \mathrm{a}$ & 3.16 & $70.42 \mathrm{a}$ \\
\hline
\end{tabular}

$*$ plant population $=22285$

\section{Conclusions}

In conclusion, the results of this study revealed that nitrogen fertilization increased most of yield parameters which are reflected in the increase of forage yield. The second season was more favorable than the first season. The yellow cultivar Wad Ashana out yielded the white one Dembi. Addition of $120 \mathrm{~kg} \mathrm{~N} /$ ha and $/$ or $160 \mathrm{~kg} \mathrm{~N} /$ ha will increase the forage yield of pearl millet significantly. This study cleared that local cultivars of pearl millet could not obtain positive grain yield due to the effect of temperature and a long day light in April - July at Shambat location, but it was good for forage yield.

\section{REFERENCES}

[1] Abdelrahman, F.I. (2007). Effect of seed rate and NPK fertilizer on growth, yield and forage quality of Rhodes grass, M.Sc. Thesis, Faculty of Agriculture, U. of K., Khartoum, Sudan.

[2] Abuali, A.I., Abdelmulla, A.A. and Idris, A.E. (2012). Character Association and Path Analysis in Pearl Millet (PennisetumglaucumL.). American Journal of Experimental Agriculture2(3): 370-381.

[3] Adam, M.Y. (2004), Effect of seed rate and nitrogen on growth and yield of teff grass, Ag. Sc. J. SS-58.

[4] Banks, S. and Stewart, T. (2008), Forage pearl millet FACT SHEET ministry of agriculture, food and rural affairs. Queens print Ontario, Canada.

[5] Dass, B. and Singh, R. (1979). Uptake of nutrients (H, P and
$\mathrm{K})$ by rain fed maize as affected by nitrogen application and soil type. J. of Indian Soc. and soil Sci. 27(2): 142-145

[6] Frank, A. B., Bauer, A. and Black, A. L. (1988). Carbohydrate, nitrogen and phosphorus concentrations of spring wheat leaves and stems, Agron. J. 81:524-528.

[7] Gomez, K.A. and Gomez, A.A. (1984). Statistical procedures for Agricultural research, 2nd edition. John Wiley and Sons lnc., New York.

[8] Ibrahim, A. E. S. (1996). Growth and forage yield of peal millet (Pennisetum americanum L.) as affected by irrigation frequency, seed rate and nitrogen in the United Arab Emirates, U. of K. J. of Agric. Sci. 4(1): 45-60.

[9] ICRISAT (2009). Pearl Millet Report, India.

[10] Khader, F.A, Odion, C.E. and Kaigama, B.k. (1979). Nitrogen fertilization and plant density for peal millet production in Northern Nigeria, Alex. J. Agric. Res. 27(4): 135-140.

[11] Maranville, W.J. (1989). Mineral uptake and utilization in sorghum and pearl millet, INTSOR MILL Annual Report. $37-42$.

[12] Reddy, M.G., Reddy, S.R., Reddy, P.R., and Subrahmanyam, K. (1988), Effect of nitrogen on nitrogen and phosphorus uptake in finger millet, Indian J. of Agron. 31(1): 29-32.

[13] Siddig, M.A. (2002), Effect of nitrogen and phosphorus fertilization on growth and yield of pearl millet, Ph.D. Thesis U. of K., Sudan.

[14] Vanderlip, R.L. (1991). Modelling millet and sorghum establishment and growth and sustainable crop production. INTSORMIL. Ann. Rep., 38 - 43.

[15] Wilson, I. (2009), Genetic enhancement and management of warm season grass species for forage and alternative uses, crop genetic: and Breeding USDA. 